Jurna I Instruksional, Volume 1, Nomor 1, oktober 2019 | 66 ISSN: $2686-5645$

\title{
MENINGKATKAN KEMAMPUAN MENULIS TEKS RECOUNT PADA SISWA DENGAN MENGGUNAKAN TEKNIK PEMETAAN SEMANTIK
}

\author{
Farhana \\ SMP Atlantis Plus \\ Email: ffehn@yahoo.com
}

\begin{abstract}
The purpose of this research is to improve the students' writing skill of recount text through semantic mapping technique. This research used qualitative method with the type of classroom action research. It was done by doing three cycles. There are three techniques used by the researcher in collecting data, they are interview, observation and test. Based on the results findings, the usage of semantic mapping technique can increase their evaluation results. The mean score of test in cycle 1 is 70.17. In cycle 2, the mean score is 75.86, the mean score in cycle 3 is 83.79. They were interest in writing recount text through semantic mapping technique. The students' positive respond can be useful to make meaningful learning activity and make them easier in understanding the material. From the explanation above, the researcher concluded that semantic mapping technique can improve the students' writing skill in recount text.
\end{abstract}

Keywords: Semantic Mapping, Writing, Recount Text, English

\begin{abstract}
Abstrak
Penelitian ini bertujuan untuk meningkatkan keterampilan menulis teks recount siswa melalui teknik pemetaan semantik. Penelitian ini menggunakan metode kualitatif dengan jenis penelitian tindakan kelas. Itu dilakukan dengan melakukan tiga siklus. Ada tiga teknik yang digunakan oleh peneliti dalam mengumpulkan data, yaitu wawancara, observasi dan tes. Berdasarkan hasil temuan, penggunaan teknik pemetaan semantik dapat meningkatkan hasil evaluasi mereka. Nilai rata-rata dari tes pada siklus 1 adalah 70.17. Pada siklus 2, skor rata-rata adalah 75.86, pada siklus 3, skor rata-rata adalah 83.79. Siswa tertarik menulis teks recount melalui teknik pemetaan semantik. Tanggapan positif siswa dapat berguna untuk membuat kegiatan pembelajaran yang bermakna dan mempermudah mereka dalam memahami materi. Dari penjelasan di atas, peneliti menyimpulkan bahwa teknik pemetaan semantik dapat meningkatkan keterampilan menulis siswa dalam teks recount.
\end{abstract}

Kata kunci: Pemetaan Semantik, Menulis, Teks Recount, Bahasa Inggris

\section{PENDAHULUAN}

Berbicara mengenai bahasa Inggris telah dianggap sebagai mata pelajaran wajib dalam kurikulum, mulai dari tingkat SMP, SMA hingga Perguruan Tinggi. Bahasa Inggris telah menjadi suatu keharusan bagi semua orang karena bahasa Inggris adalah bahasa internasional, yang sebagian besar negara di dunia menggunakan bahasa ini. Tujuan belajar bahasa Inggris itu sendiri adalah untuk mempersiapkan generasi muda Indonesia untuk bersaing secara global. Sehingga generasi muda nantinya dapat berinteraksi secara luas dengan kemampuan bahasa internasional yang disediakan adalah baik dan benar. Selain itu, digunakan sebagai media untuk berkomunikasi juga digunakan untuk mengontrol perkembangan teknologi yang menuntut kita untuk belajar lebih dalam. Selain itu, bahasa Inggris adalah alat untuk berkomunikasi secara lisan dan tertulis. Berkomunikasi adalah untuk memahami dan mengungkapkan informasi, pikiran, perasaan dan mengembangkan ilmu pengetahuan, teknologi dan budaya. Keterampilan berkomunikasi adalah kemampuan untuk menghasilkan teks secara lisan dan tertulis untuk diwujudkan dalam empat keterampilan bahasa, yaitu mendengarkan, berbicara, membaca dan menulis. Keempat keterampilan tersebut digunakan dalam pembelajaran bahasa Inggris di tingkat SMP dan SMA sehingga lulusan dapat berkomunikasi dan 
wacana dalam bahasa Inggris pada tingkat tertentu.

Pelajaran bahasa Inggris bukanlah hal baru karena bahasa ini adalah mata pelajaran wajib bagi siswa di Indonesia, sehingga mau tidak mau mereka harus mengikuti pembelajaran bahasa Inggris. Keputusan Pemerintah untuk mengatur bahasa Inggris sebagai salah satu mata pelajaran wajib dalam berbagai hal sekunder sangat beralasan untuk mempersiapkan generasi Indonesia untuk bersaing secara global. Seiring waktu, belajar bahasa Inggris dianggap sebagai kebutuhan yang tidak dapat diabaikan. Misalnya, sebagai salah satu syarat penerimaan siswa di perguruan tinggi, selain penguasaan bahasa Inggris dibuat sebagai salah satu prasyarat dalam rekrutmen karyawan. Ada beberapa keterampilan dalam Bahasa Inggris, salah satunya keterampilan menulis.

Rendahnya kemampuan menulis siswa merupakan salah satu indikasi kelemahan saat kesulitan belajar. Peneliti mengidentifikasi kelemahan dan kesulitan belajar yang menyebabkan rendahnya minat dan motivasi siswa terhadap kegiatan menulis. Sebagian besar siswa menulis biasanya hanya karena tugas yang diberikan oleh guru. Mereka tidak terbiasa menulis atas inisiatif mereka sendiri. Ketika mereka menulis, mereka tidak memiliki kesempatan untuk menganalisis hasil tulisannya. Biasanya hanya guru yang tahu kualitas tulisan mereka. Hasil observasi, peneliti berasumsi bahwa siswa kurang dalam kemampuan menulis teks recount dengan benar. Setelah mengamati tugas dan melihat nilai dalam menulis siswa maka faktor utama ketidakmampuan siswa untuk menulis teks recount dengan baik dan benar karena pemilihan kata yang tidak tepat dan penerapan tata bahasa yang salah. Hasil wawancara dan berbagi ide dengan guru bahasa Inggris memperoleh kesimpulan adalah perlu upaya untuk mengoptimalkan hasil penelitian, terutama seperti keterampilan, terutama menulis, pendekatan mengajar diperlukan lebih banyak pada kegiatan pembelajaran dan kreativitas siswa. Saat ini para siswa menulis tidak hanya melalui satu tahap, tetapi beberapa tahap.

Oleh karena itu, upaya untuk menulis teks, khususnya pengkondisian ulang dengan penelitian tindakan kelas harus dilakukan. Menulis teks recount berarti siswa mampu mengembangkan kemampuan menulis jenis teks dalam bentuk recount. Teks penghitungan ulang adalah bentuk yang menggambarkan peristiwa yang telah terjadi atau peristiwa yang telah berlalu dan itu adalah salah satu bentuk yang diajarkan dari beberapa jenis teks. Berdasarkan pelajaran, idealnya pembelajar dapat membuat menulis teks recount. Karena tulisan yang ditulis adalah ide atau ide yang mereka alami dalam kehidupan mereka, selain di tingkat SMP, mereka sudah belajar. Berdasarkan hasil observasi siswa dan guru itu harus memiliki nilai yang di dalamnya lebih dari $75 \%$ atau di atas kriteria minimum (77).

Namun pada kenyataannya, hanya 40 persen dari nilai standar, atau hanya 18 siswa dari 29 siswa yang menghargai memuaskan, dan yang lainnya tidak menghasilkan sesuai dengan harapan. Jadi pada umumnya, peserta didik belum mampu membuat tulisan teks recount, karena mereka berpikir bahwa menulis sangat sulit untuk menuangkan ide atau ide membentuk paragraf yang baik dan harus tahu langkahlangkah atau kriteria dalam penulisan teks recount. Beberapa penyebab kelemahan dalam pelajaran bahasa Inggris di SMP Atlantis Plus, dipengaruhi oleh faktor internal, pertama berhubungan dengan guru bahasa Inggris itu sendiri yang dapat membuat siswa berbicara di sekolah, sedangkan guru yang mendidik mata pelajaran lain tidak berpartisipasi meskipun gerakan dari program harus dilaksanakan oleh semua pendidik bahasa, cara bagaimana mengajar guru masih menggunakan paradigma lama, terbatas bagaimana memotivasi siswa akan mendapatkan kesadaran bahasa di lingkungan sekolah. Sementara, relevansi siswa juga terlibat, fakta ini disebabkan oleh perspektif siswa terhadap bahasa Inggris yang membosankan, terlalu sulit, tidak ada keberanian untuk berlatih, rendahnya penguasaan tata bahasa, dan tidak ada ide. Ketiga, kurangnya kebijakan sekolah tentang penghargaan dan hukuman bagi siswa, dan penciptaan iklim bahasa belum terealisasi, dan program bahasa Inggris tidak mengalami kemajuan. Faktor lain yang juga mempengaruhi adalah faktor dari luar peran bahwa orang tua cenderung rumah tangga bahwa anak-anak tidak dapat berbicara bahasa Inggris tidak berarti bahwa anak-anak yang gagal, kurangnya motivasi, dan kurangnya fasilitas listrik 
mendukung anak-anak belajar di rumah. Masalah lain juga disebabkan oleh teman dan masyarakat yang lebih larut dalam mengetahui gaya hidup asosiasi daripada intelektual dan bahasa.

Ada banyak teknik yang dapat digunakan oleh para guru untuk meningkatkan penguasaan penulisan dalam pelajaran bahasa Inggris. Seperti pemetaan semantik adalah salah satu bagian dari teknik secara visual menampilkan koneksi berbasis makna antara kata atau frase dan sekumpulan kata atau konsep terkait. Hasil penelitian yang telah dilakukan oleh Mah Boon Yih dan bereksperimen menggunakan teknik ini efektif adalah: "Pemetaan semantik membantu untuk memperoleh daftar kata-kata yang terkait dengan topik yang diberikan. Aktivitas di atas tentang penggunaan pemetaan semantik sebagai teknik pra-penulisan telah ditemukan berhasil di antara subjek dalam tulisan.” (Mah Boon Yih, 2011: 2). Peta semantik membantu siswa, terutama siswa yang sedang berjuang dan mereka yang kurang, untuk mengidentifikasi, memahami, dan mengingat arti kata-kata yang mereka baca dalam teks. Pilihan untuk meningkatkan kemampuan siswa menulis, terutama dalam hal teks recount.

Pemahaman lanjutan tentang pemetaan semantik secara konseptual adalah teknik yang digunakan dengan bagaimana membuat konsep makna kata terkait satu sama lain kata-kata di atas kertas untuk membuat pemetaan semantik. Teknik ini juga dapat digunakan pada penulisan materi untuk mengingat kata-kata untuk didengar atau dibaca. Pemetaan semantik adalah salah satu teknik yang paling membantu dalam pendekatan kemampuan menulis siswa. Biasanya, dalam brainstorming, ide dari satu siswa akan memicu ide dari siswa lain dalam proses pemikiran reaksi berantai. Keuntungan lain dari pemetaan semantik adalah: memotivasi siswa dari semua tingkatan, mengintegrasikan pemikiran dengan membaca, mengintegrasikan penilaian dengan pengajaran, dan membuat penilaian mengenai instruksi yang tepat yang diperlukan. Lain alasan peneliti dan diperkuat oleh bukti empiris bahwa teknik ini memiliki manfaat: "Pemetaan semantik membutuhkan guru dan siswa bekerja sama untuk membangun peta diagram yang menunjukkan hubungan antara kosakata yang disarankan oleh guru, kosakata oleh siswa dan kosakata yang ditemukan dalam teks bacaan. Pemetaan semantik membantu siswa untuk mempelajari kata-kata yang tidak dikenal melalui kata-kata yang dikenal dalam jaringan semantik terkait." (Yesim Dilek, 2012: 1)

Berdasarkan latar belakang di atas maka dipandang perlu untuk meneliti bagaimana meningkatkan kemampuan menulis teks recount pada siswa, salah satu solusi yang dapat digunakan adalah melalui teknik pemetaan semantik. Berdasarkan rumusan pokok masalah tersebut dapat diperinci menjadi beberapa rumusan masalah sebagai berikut: (1) bagaimana hasil kemampuan siswa dalam menulis teks recount? (2) apa kesulitan yang dihadapi oleh siswa SMP untuk menulis teks recount? (3) apa strategi dan langkah yang digunakan oleh peneliti untuk meningkatkan kemampuan menulis teks recount siswa Inggris? (4) bagaimana teknik pemetaan semantik dapat meningkatkan kemampuan menulis bahasa Inggris siswa SMP? (5) bagaimana proses menggunakan teknik pemetaan semantik dalam keterampilan menulis teks recount di kelas? (6) bagaimana cara guru meningkatkan keterampilan menulis siswa dari teks recount menggunakan teknik pemetaan semantik di kelas?. Berangkat dari rumusan masalah di atas maka tujuan yang ingin dicapai dalam penelitian ini adalah: (1) mampu meningkatkan kemampuan menulis pada siswa dalam teks recount; (2) mendesain teknik pemetaan semantik dalam pembelajaran bahasa Inggris agar menarik untuk siswa; (3) mendeskripsikan hasil karya tulis siswa dalam teks recount menggunakan teknik tersebut.

Manfaat teoritis dari hasil penelitian ini diharapkan dapat menjadi masukan dalam pengembangan menulis teks $\neg$ recount atau keterampilan lainnya yang menggunakan teknik pemetaan semantik. Selanjutnya manfaat praktis dari hasil penelitian ini adalah sebagai berikut: (1) bagi siswa, memberikan pengalaman baru dalam mempelajari bahasa Inggris, terutama dalam menulis dan membuat siswa memahami bahwa menulis tidak sulit dan teknik tersebut membantu mereka untuk menciptakan ide-ide kata-kata sendiri dalam bentuk perspektif; (2) bagi guru, melalui penerapan teknik pemetaan 
semantik dalam keterampilan menulis teks recount, guru sebagai fasilitator akan memudahkan ketika siswa mendapatkan kesulitan dengan memberikan pemetaan semantik, memberikan bimbingan dalam penyusunan teks recount dengan makna pemetaan semantik: (3) bagi institusi, meningkatkan kemampuan siswa, mereka harus lebih memperhatikan apa yang dibutuhkan siswa dan guru dalam proses pembelajaran sehingga proses pembelajaran dapat berjalan dengan baik. Peneliti berharap penelitian ini dapat memberikan lebih banyak solusi untuk sekolah dalam mereformasi proses pembelajaran guru di kelas; (4) bagi peneliti, mendapatkan banyak pengalaman baru tentang mengajar bahasa Inggris dengan menggunakan teknik pemetaan semantik, dan mendapatkan teknik yang menarik untuk meningkatkan keterampilan menulis siswa dan peneliti melalui teknik pemetaan semantik. Jadi, ketika para peneliti menjadi guru bahasa Inggris yang nyata, dia dapat menggunakan pengalaman untuk mengajar bahasa Inggris dan dapat lebih meningkatkan kemampuan kemampuan menulis untuk dirinya sendiri.

Tabel 1. Rubrik Penilaian Menulis Siswa: Khusus Teks Recount

\begin{tabular}{|c|c|}
\hline $\begin{array}{l}\text { Focus/Organization } \\
\text { - The writing expresses the views, thoughts, or feelings of the writer. } \\
\text { - The significance or main idea of the views, thoughts, or feelings is } \\
\text { clear. } \\
\text { - The writing is organized in a way appropriate to the purpose and } \\
\text { audience. }\end{array}$ & Score___ $/ 35$ \\
\hline $\begin{array}{l}\text { Elaboration/Support/Style } \\
\text { - Ideas, opinions, and general statements are supported by specific } \\
\text { details. } \\
\text { - Vivid language is used to add interest to the writing. } \\
\text { - Transition words help make the organization clear. }\end{array}$ & Score __ \\
\hline $\begin{array}{l}\text { Grammar, Usage, and Mechanics } \\
\text { - The writing is free of misspellings, and words are capitalized } \\
\text { correctly. } \\
\text { - Sentences are punctuated correctly, and the piece is free of fragments } \\
\text { and run-ons. } \\
\text { - The paper is neat, legible, and presented in an appropriate format. }\end{array}$ & Score ___ \\
\hline
\end{tabular}

\section{Teks Recount}

Sebuah teks recount ditulis untuk membuat laporan tentang pengalaman dari serangkaian acara terkait. Penghitungan ulang ditulis untuk menginformasikan suatu peristiwa atau untuk menghibur orang. Teks recount adalah fungsi teks seperti menceritakan insiden di masa lalu. (Peter Knapp, 2005: 223). Teks ini yang menceritakan tentang sesuatu yang terjadi di masa lalu. Detail dalam penghitungan ulang dapat mencakup apa yang terjadi, siapa yang terlibat, di mana itu terjadi, kapan itu terjadi dan mengapa itu terjadi. Tujuan atau sasarannya adalah untuk menghibur atau memberi informasi tentang aktivitas masa lalu kepada pembaca atau pendengar.

Menulis ulang teks dapat berupa informasi faktual, seperti berita atau informasi prosedural, seperti memberi tahu seseorang bagaimana Anda membangun sesuatu atau informasi pribadi, seperti liburan keluarga atau pendapat Anda tentang suatu subjek. Struktur dasar teks recount adalah sebagai berikut: (1) orientasi, urutan dari serangkaian peristiwa. Setiap cerita, tidak peduli betapa sederhananya, membutuhkan orientasi. Sesungguhnya, mustahil 
untuk menceritakan sebuah kisah kecuali kita melihat bahwa ada karakter yang dibentuk pada waktu dan tempat tertentu. (2) urutan kejadian/peristiwa, bagaimanapun, lebih kompleks daripada peristiwa sebelumnya. Di sini siswa memberikan catatan tentang semua kegiatan penting yang terjadi pada perjalanan itu. (3) reorientasi, ini opsional. Ini terdiri dari penutupan acara / akhir. Ini menyatakan komentar pribadi penulis pada cerita.

\section{Teknik Pemetaan Semantik}

Semantik adalah studi tentang bahasa makna. Dalam teori bahwa sifat semantik item leksikal sepenuhnya tercermin dalam aspekaspek yang sesuai dari relasi yang dikontraknya dengan konteks aktual dan potensial. Implikasi penuh dari ini akan menjadi lebih jelas ketika hasil eksposisi berlangsung. (Cruse, 1986: 1). Ini adalah fakta bahwa makna adalah bagian dari bahasa, tetapi definisi ini belum digambarkan secara jelas dan diberikan perlakuan yang adil dalam studi bahasa hingga baru-baru ini. Dalam linguistik tradisional, bahasa dipandang sebagai kosakata yang terkandung dalam karya sastra. Dalam studi bahasa, definisi bahasa kadangkadang berdasarkan makna, dan kadang-kadang pada fungsi. Pernyataan bahwa kata benda adalah nama orang atau benda, atau kalimat adalah ekspresi pemikiran lengkap, adalah definisi yang didasarkan pada makna. Sebaliknya, pernyataan bahwa kata sifat adalah kata yang memodifikasi kata benda, atau kata keterangan adalah kata yang mengubah kata lain mengharapkan nomina, adalah definisi yang didasarkan pada fungsi. Prestasi luar biasa dalam studi makna dalam linguistik tradisional adalah etimologi - studi tentang asal-usul makna kata. Studi tentang makna dalam linguistik tradisional belum jelas menunjukkan apa artinya.

$$
\text { Speidel menyatakan bahwa }
$$

peta/pemetaan adalah pengaturan kosakata (konsep) tentang suatu topik. (Speidel, 1982: 35). Konsep dikategorikan dalam beberapa cara. Pembuatan peta semantik adalah prosedur untuk membangun jembatan antara yang dikenal dan yang baru. Peta tersebut memberi tahu guru apa yang siswa ketahui tentang suatu topik dan memberikan titik jangkar siswa di mana mereka dapat melampirkan informasi dan konsep baru yang akan mereka hadapi. Pemetaan semantik secara konsisten dikaitkan dengan skor yang lebih tinggi pada item tes yang mengukur pemahaman spesifik, seperti mengingat kembali gagasan teks dan mengingat konsep-konsep kunci. Pemetaan semantik adalah teknik untuk memvisualisasikan struktur pengetahuan. Karena pengetahuan yang dinyatakan dalam peta sebagian besar semantik, peta konsep kadangkadang disebut jaringan semantik. Seringkali diklaim bahwa pemetaan konsep memiliki kesamaan dengan struktur memori jangka panjang. Alih-alih menggambarkan semua konsep dan hubungan mereka dalam teks, satu cara memilih untuk menggambar peta yang menunjukkan konsep dan relasi dalam grafik atau jaringan.

Teknik pemetaan semantik juga merupakan cara untuk membantu siswa berpikir lebih kreatif untuk mengasosiasikan ide dengan lebih mudah. Dalam teori menyatakan bahwa peta semantik adalah pengaturan bentuk seperti kotak, persegi panjang, segitiga, lingkaran, dan sebagainya, dihubungkan oleh garis dan / atau panah yang ditarik antara dan di antara gambar. Ini berarti pemetaan semantik dapat digunakan untuk menjelaskan objek tertentu (diagram, garis, kotak, panah, dan lingkaran) untuk menunjukkan hubungan mereka. Dia juga menyatakan bahwa akan lebih mudah bagi siswa untuk menulis teks laporan dengan mengacu pada kata-kata terkait sebanyak mungkin, mengidentifikasi karakteristik dari kata yang diberikan. Oleh karena itu, pemetaan semantik dirancang sebagai jenis grafik organizer spesifik untuk mendukung atau membantu siswa untuk menjadi lebih strategis secara tertulis. Dalam istilah konseptual, peta semantik berisi informasi verbal di dalam dan di antara bentuk-bentuk yang menciptakan pola dan /atau hubungan ide. 
Jurnal Instruksional, Volume 1, Nomor 1, Oktober 2019 |71 ISSN: 2686-5645

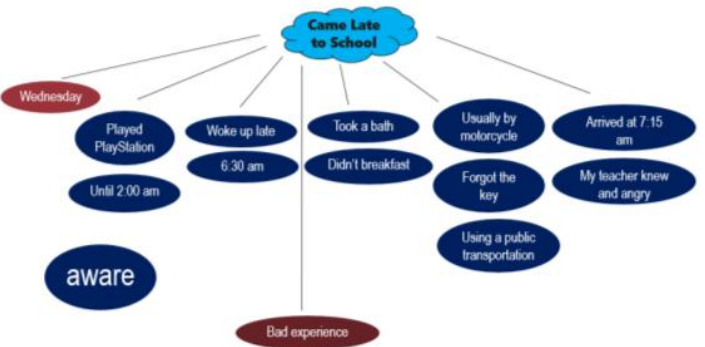

Gambar 1. Contoh Karya Pemetaan Semantik (diagram)

Disimpulkan bahwa pemetaan semantik adalah jenis pra-penulisan yang memungkinkan para siswa untuk mengeksplorasi banyak ide segera setelah mereka muncul kepada mereka. Seperti brainstorming asosiasi gratis, pemetaan semantik memungkinkan siswa untuk memulai tanpa ide yang jelas.

\section{METODE PENELITIAN}

Penelitian ini menggunakan metode paradigma kualitatif dengan peningkatan penelitian tindakan kelas. Studi tentang penelitian tindakan kelas menunjukkan sebagai proses di mana guru menyelidiki pengajaran dan pembelajaran untuk meningkatkan masalah belajar siswa. Penelitian tindakan kelas adalah suatu proses di mana peserta menguji praktik pendidikan mereka sendiri secara sistematis dan hati-hati, menggunakan teknik penelitian. Hal ini memberikan makna bahwa penelitian tindakan menurut (Valsha Koshy, 2005: 9) adalah penyelidikan konstruktif (constructive enquiry), di mana peneliti mengkonstruksi pengetahuannya tentang isu-isu tertentu melalui perencanaan, tindakan, evaluasi, modifikasi dan belajar dari pengalaman. Ia adalah proses pembelajaran yang berkelanjutan, yang mengharuskan peneliti belajar dan juga membagi pengetahuan yang baru diperolehnya dengan mereka yang bisa memperoleh manfaat dari pengetahuan tersebut.

Langkah-langkah Penelitian

Pengumpulan data ini menggunakan data, yang merupakan hasil dari penerapan pengajaran menulis teks recount melalui teknik pemetaan semantik. Penelitian tindakan kelas dimulai dengan siklus kecil perencanaan, tindakan, pengamatan dan refleksi yang dapat membantu mendefinisikan masalah, ide, dan asumsi dengan lebih jelas. Bentuk-bentuk langkah penelitian yang akan dilakukan oleh peneliti adalah: (1) perencanaan, beberapa tindakan atau langkah yang diambil oleh guru ketika akan memulai tindakan. Yakni guru mempersiapkan apa yang akan diajarkan kepada siswa, kapan dan bagaimana melakukannya, di mana dilakukan, peralatan dan fasilitas akan digunakan dan tindakan apa yang harus dilakukan setelah perencanaan selesai; (2) tindakan, implementasi adalah hasil dari tindakan yang diambil setelah perencanaan. Dengan prioritas yang lebih tinggi untuk: apakah ada penyesuaian antara pelaksanaan rencana, apakah proses yang dilakukan sudah sesuai dengan perencanaan atau tidak, bagaimana bentuk tindakan, berhasil atau tidak; (3) pengamatan, proses perencanaan mengamati dilakukan setelah pembelajaran dilakukan; (4) refleksi, langkah atau hasil temuan setelah melakukan beberapa langkah ke arah dalam pelaksanaan tindakan selanjutnya. Peneliti memberikan tes menulis melalui siklus 1 , siklus 2 dan siklus 3. Setiap siklus terdiri dari perencanaan, tindakan, pengamatan dan refleksi. Teknik Pengumpulan Data

Penelitian ini dilakukan dengan mengambil sumber data dari siswa dan kolaborator. Peneliti memilih pada siswa kelas VIII SMP Atlantis Plus berlokasi di Jalan Pramuka Raya No. 9 Kelurahan Mampang Kecamatan Pancoranmas Kota Depok sebagai informan. Jumlah total siswa adalah 29, ada 12 anak laki-laki dan 17 perempuan. Dan juga peneliti mendapatkan data dari guru bahasa Inggris sebagai kunci informan. Data tentang peningkatan pemahaman membaca siswa diperoleh dengan melakukan observasi di kelas guna mendapatkan informasi yang dibutuhkan, dengan mengamati situasi dan kondisi kelas dalam proses belajar mengajar, hasil pengamatan dicatat dalam bentuk catatan lapangan; melakukan wawancara setelah pertemuan kelas guna mengetahui manfaat dari tindakan; dan tes menulis diberikan sebelum dan sesudah peneliti 
melakukan tindakan, guna untuk mengukur keterampilan menulis siswa.

Untuk menganalisis data, peneliti melakukan beberapa langkah sebagai berikut: (1) pengurangan data, semua data direkam dan dianalisis secara detail melalui reduksi data. Pengurangan data akan membuat resume, memilih yang penting dan membuang yang tidak perlu; (2) deskripsi data, target peneliti dari penelitian ini adalah $100 \%$ untuk setiap siklus tes instrumen. Peneliti mempelajari data dalam setiap siklus, menganalisis kelemahan dan masalah selama kegiatan dan menentukan solusi apa untuk menyelesaikan masalah dalam siklus 1 ke siklus 2 dan siklus 3 . Peneliti menampilkan hasil dari setiap siklus dan memberikan verifikasi setiap siklus kepada kolaborator tentang skor daftar penulisan; (3) verifikasi data, pada akhir penelitian, peneliti membuat kesimpulan tentang peningkatan keterampilan menulis siswa menggunakan teks recount melalui teknik pemetaan semantik. Langkah selanjutnya adalah membuat rata-rata dari hasil tes yang telah diambil sebelumnya. Peneliti menjelaskan proses untuk memvalidasi data melalui triangulasi dengan membandingkan data yang dikumpulkan dari berbagai sumber, yaitu: hasil tes, observasi dan wawancara. Indikator keberhasilan peningkatan teknik pemetaan semantik pada siklus pembelajaran teks recount dari makalah ini adalah skor yang didapat berdasarkan Kriteria Ketuntasan Minimal untuk mata pelajaran Bahasa Inggris 77 dan target pembelajaran $100 \%$.

\section{HASIL DAN PEMBAHASAN}

pertemuan, ditemukan hanya 9 siswa dari 29 siswa yang mendapatkan nilai di atas KKM dengan rata-rata kelas 70.17. Setelah menganalisa data dengan mengamati, peneliti dan guru membahas tentang kesimpulan dari pelaksanaan tindakan. Berdasarkan pengamatan selama proses pembelajaran dalam menulis teks recount melalui pemetaan semantik tidak terlalu efektif. Ada beberapa siswa yang mengalami kesulitan dalam membuat teks recount melalui teknik pemetaan semantik. Karena mereka merasa kesulitan dalam menghasilkan dan mengatur ide-ide, kurangnya kosa kata, fungsi gramatikal dan mereka tidak bisa menggambar. Jadi, mereka tidak memiliki semangat yang cukup untuk membuat teks recount melalui pemetaan semantik. Para siswa perlu ditekankan bahwa teknik pemetaan semantik bukanlah tentang menggambar garis atau gambar. Mereka lebih fokus pada bagaimana membuat gambar yang bagus daripada mengekspresikan ide-ide mereka. Pemetaan semantik adalah teknik yang mengekspresikan ide dalam selembar kertas yang ditarik. Ada gambar di sana, tetapi fungsinya adalah untuk membuat seseorang lebih mudah mengingat sesuatu. Tidak penting gambarnya bagus atau tidak, tetapi yang paling penting adalah menghasilkan dan mengatur ide atau konsep.

Pada siklus berikutnya, para siswa akan dibagi berpasangan dengan teman-teman mereka. Para siswa akan membuat teks recount melalui teknik pemetaan semantik dan disajikan di depan kelas secara lisan. Tindakan ini dilakukan untuk membuat para siswa membandingkan ide-ide mereka dengan temanteman mereka dan saling membantu. Selain itu, tindakan ini membuat siswa lebih percaya diri. Itu artinya mereka tidak selalu bertanya kepada guru atau peneliti jika mereka tidak mengerti. Dalam melakukan latihan secara individual, karena itu membantu mereka untuk memahami. Peneliti menggunakan tema bad thing happened or funny experienced dalam tiga pertemuan, para siswa mempresentasikan hasil karya pemetaan semantik dalam bentuk gambar dan penuh warna serta hasil tulis dalam bentuk kelompok. Siklus kedua ini meningkat 5.69 dengan ditemukan 18 siswa dari 29 siswa yang mendapatkan nilai di atas KKM dengan rata-rata kelas 75.86.

Salah satu faktor yang menyebabkan meningkatnya skor adalah materi tes hampir sama dengan materi yang telah dipelajari. Kondisi itu membuat siswa lebih mudah melakukan tes daripada siklus 1. Pada siklus berikutnya, peneliti masih menjelaskan tentang materi teks recount. Kemudian siswa melakukan latihan dan tes di akhir siklus 3. Dalam melakukan latihan itu sendiri secara individu, karena itu membantu mereka melakukan latihan dan mengerti tentang itu. Latihan itu sama seperti dari siklus 1 dan siklus 2. Dalam siklus terakhir peneliti memberikan tema tentang dream future about business untuk tes terakhir yang dilakukan oleh siswa. Berdasarkan pengamatan selama proses pembelajaran pada 
siklus 3, aktivitas pembelajaran dalam menulis teks recount dan melakukan latihan lebih efektif daripada di siklus 2. Hal ini dapat dilihat dari siswa yang sangat sadar ketika mereka menulis teks recount dan jarang diminta untuk guru atau peneliti tentang itu. Dalam siklus ini, semua siswa melakukan tugas dengan baik. Berdasarkan wawancara yang diberikan kepada siswa, diketahui bahwa siswa lebih antusias dan sadar dalam menulis teks recount dan melakukan latihan daripada di siklus 2. Skor rata-rata dari tes di siklus 3 lebih baik daripada di siklus 2 . Skor adalah 83,79 atau meningkat 7,93 daripada di siklus 2 adalah 75,86. Itu karena mereka sudah terbiasa menulis, melakukan latihan dan tes.

Tabel 2. Hasil dari 3 siklus

\begin{tabular}{|l|c|l|}
\hline Nilai & Rata-rata & Persentase \\
\hline Siklus 1 & 70.17 & $31.03 \%$ \\
\hline Siklus 2 & 75.86 & $62.06 \%$ \\
\hline Siklus 3 & 83.79 & $100 \%$ \\
\hline
\end{tabular}

\section{KESIMPULAN}

Berdasarkan hasil penelitian dan pembahasan yang telah dikemukakan sebelumnya dapat disimpulkan sebagai berikut: pertama, Peningkatan keterampilan menulis siswa dalam bahan teks recount dapat dilihat dari skor rata-rata tulisan siswa yang meningkat setiap siklus. Pada siklus 1, skor rata-rata tes adalah 70,17. Hanya ada 9 siswa atau $31,03 \%$ dari siswa yang lulus Kriteria Minimal Penguasaan - Kriteria Ketuntasan Minimal (KKM). Pada siklus 2, skor rata-rata adalah 75,86 atau meningkat 5,69 dibanding siklus 1 . Ada 18 siswa atau $62,06 \%$ siswa yang lulus Kriteria Penguasaan Minimal - Kriteria Ketuntasan Minimal (KKM). Pada siklus 3, skor rata-rata adalah 83,79 atau meningkat 7,93 dibandingkan pada siklus 2. Ada semua siswa atau $100 \%$ dari siswa yang lulus Kriteria Penguasaan Minimum - Kriteria Ketuntasan Minimal (KKM). Kedua, Pada siklus 1, siswa merasa tertarik dalam menulis teks recount melalui teknik pemetaan semantik meskipun
Hasil post-test 3 menunjukkan bahwa $100 \%$ siswa yang mendapat skor di atas Kriteria Minimal Penguasaan - Kriteria Ketuntasan Minimal (KKM). Oleh karena itu, peneliti dan guru memutuskan untuk menghentikan penelitian tindakan kelas, karena sudah berhasil. Berdasarkan hasil evaluasi antara peneliti dan guru, dapat diasumsikan bahwa pelaksanaan penelitian tindakan kelas dalam meningkatkan keterampilan menulis siswa melalui teknik pemetaan semantik sesuai dengan perencanaan yang telah dibahas oleh peneliti dan peneliti. guru sebelumnya. Dalam hal ini, setiap tindakan direncanakan sebaik mungkin. Jadi, kegiatan menulis itu bisa terlaksana dengan baik. mereka masih bingung bagaimana membuat teks recount melalui teknik pemetaan semantik. Dalam siklus 2, keterampilan menulis siswa dalam membuat teks recount melalui teknik pemetaan semantik lebih baik daripada di siklus 1 , tidak hanya dapat meningkatkan keterampilan menulis mereka tetapi juga mereka dapat meningkatkan keterampilan berbicara mereka dengan menyajikan teks recount mereka melalui teknik pemetaan semantik. Mereka terlihat menarik ketika guru memberikan hadiah atau poin untuk siswa yang disajikan di depan kelas. Dalam siklus 3, siswa lebih antusias dalam menulis teks recount melalui teknik pemetaan semantik. Mereka terlihat lebih bersemangat juga ketika mereka melakukan latihan dan tes, karena materi latihan dan tes hampir sama dengan materi yang telah dipelajari, dan topiknya sangat menarik bagi mereka. Ketiga, Teknik pemetaan semantik adalah teknik yang baik yang dapat digunakan oleh guru dan siswa dalam proses belajar mengajar, terutama dalam mengajar dan belajar tentang menulis teks 
recount. Dalam teknik ini, para siswa menulis topik di tengah dan mendukung ide-ide, yang berarti di sekitarnya. Topik dan ide pendukungnya, artinya dapat dihubungkan dengan menggunakan diagram, garis, kotak, panah, dan lingkaran untuk membuatnya dapat dikelola. Ini berarti bahwa dengan menggunakan teknik pemetaan semantik dalam mengajar teks recount, guru dan siswa akan mencapai tujuan dari pelajaran. Para siswa dapat dengan mudah memahami pelajaran dan mereka dapat menulis teks penghitungan ulang dalam struktur generik yang benar. Selain itu, teknik ini sangat membantu bagi siswa untuk mengembangkan dan mengatur ide-ide mereka secara sistematis dan untuk membuat siswa termotivasi untuk menulis teks yang baik terutama teks recount.

\section{REFERENSI}

Cruse, D.A. 1986. Lexical Semantics. New York: Cambridge University.

Dilek, Yesim and Nurcihan Yuruk. 2012. Using Semantic Mapping Technique in Vocabulary Teaching at Pre-intermediate Level. Turkey: Selcuk University, Hacenepe University.

Glencoe. 2006. Literature Reading with Purpose 'Rubrics for Assessing Student Writing, Listening, and Speaking - Middle School'. New York: McGraw - Hill Companies, Inc.

Jozsef, Horvath. 2001. Advanced Writing in English as A Foreign Language. Hungaria: Lingua Franca Csoport, University of Pecs.

Knapp, Peter and Megan Watkins. 2005. Genre, Text, Grammar Technologies for Teaching and Assessing Writing. Australia: University of New South Wales Press Ltd.

Murray, D. M. 1987. Write to Learn. New York: Holt, Rinehart, and Winston.

Morsey, Stephen. 1976. The Montreal Journal of Poetics. Canada: Vehicula Press.

Speidel, Gisele E. 1982. Oral Language in a Successful Reading Program or Hawaiian Children.

Yih, Mah Boon. 2011. A Visual and Structured Pre-writing Strategy in the Process of Essay Writing. Malaysia: Academy of Language Studies Universiti Teknologi MARA (UiTM) Cawangan Pulau Pinang. 
Jurnal Instruksional, Volume 1, Nomor 1, Oktober 2019 | 75 ISSN: 2686-5645 